\title{
Üliõpilaste akadeemilise kirjaoskuse arendamine Vikipeedia ülesande kaudu
}

\author{
Riina Reinsalu ${ }^{\text {al }}$, Sirli Zupping ${ }^{\mathrm{a}}$, Ene Voolaid ${ }^{\mathrm{b}}$ \\ ${ }^{a}$ Tartu Ülikooli eesti ja üldkeeleteaduse instituut \\ ${ }^{b}$ Tartu Ülikooli personaliarenduskeskus
}

\begin{abstract}
Annotatsioon
Üliõpilaste akadeemilise kirjaoskuse arendamine on üks ülikooliõpingutele seatud eesmärke, kuid selle täitmist võivad takistada mitmesugused tegurid, sh üliõpilaste vähene huvi kirjutamisülesande vastu. Üks võimalus suurendada üliõpilaste huvi on asendada traditsiooniline referaat või essee veebis vabalt kättesaadava vikiartikliga. Siinses uurimuses on seatud eesmärgiks välja selgitada vikiülesande võimalused toetada üliõpilaste akadeemilise kirjaoskuse arengut. Tartu Ülikooli väljendusõpetuse kursuste õppejõudude, õppeassistentide ja üliõpilastega tehtud fookusrühma intervjuudest ilmneb, et vikiartikli ülesande kaudu saab peale kirjutamisoskuse muu hulgas arendada üliõpilaste digi- ja infopädevust, uurimisja analüüsioskust. Ühtlasi on Vikipeediasse kui avalikku veebientsüklopeediasse kirjutamine tugev motivaator, mis sunnib üliõpilasi pingutama, kuid see võib osa üliõpilaste jaoks olla ka stressiallikas, sest nad tunnevad suurt vastutust loodud artikli eest.
\end{abstract}

Võtmesõnad: akadeemiline tekst, väljendusoskus, väljendusõpetus, eesti keel

\section{Sissejuhatus}

Wikipedia on veebientsüklopeedia, mis loodi 2001. aastal ingliskeelsena, kuid millel on nüüdseks 303 keeleversiooni, sh eestikeelne Vikipeedia. Wikipedia erineb traditsioonilistest entsüklopeediatest kasutatava vikitehnoloogia poolest, mis võimaldab igaühel muuta veebilehitsejas saidi sisu ja vaadata varasemaid versioone (Emigh \& Herring, 2005). Selline koostöine keskkond on andnud kirjutaja ja lugeja suhtele täiesti uue mõõtme (Kuteeva, 2011). Kui traditsiooniline entsüklopeedia esindab ühesuunalist suhtlust - eksperdist 
kirjutaja informeerib lugejat, pakkudes talle teadmisi, mille õigsuses üldjuhul ei kahelda (Crovitz \& Smoot, 2009) -, siis Wikipedia vahendusel toimuv suhtlus on mitmesuunaline, sest lugejad võivad samal ajal olla ka autorid. Võimalus osaleda koostöises kirjutamises, vaadata muudatuste ajalugu ning suhelda teiste lugejate ja kirjutajatega, et saada neilt tagasisidet, muudab Wikipedia eripäraseks keskkonnaks (Fessakis \& Zoumpatianou, 2013). Uusi artikleid kirjutada või olemasolevaid täiendada võivad kõik huvilised - see võimaldab koondada Wikipediasse suurel hulgal ajakohast infot, mis on kõigile tasuta kättesaadav.

Kuna Wikipediat on lihtne kasutada, artiklid on veebis tasuta kättesaadavad ning neid lisatakse ja täiendatakse pidevalt, on Wikipedia leidnud laialdast kasutust (Fessakis \& Zoumpatianou, 2013), seda ka õpilaste ja üliõpilaste ${ }^{2}$ hulgas. See on toonud aga kaasa mitmesuguseid probleeme. Üks osa probleemidest tuleneb vikikeskkonna anonüümsusest. Kuigi Wikipedias muudatuste tegemine jätab alati maha jälje, mis sunnib kirjutajat vastutama loodud teksti eest, hälbivad selle tavad lääne teadusmaailma omadest, kus nimelisel autorsusel on tähtis koht (Miller, 2005). Akadeemilise ringkonna esindajatel on raske vikiartiklitega harjuda, sest need on anonüümsete isikute kollektiivse, mitte nimeliselt tuntud autoriteetide individuaalse loomingu tulemus ning need ei allu tavapärastele autoriõiguse põhimõtetele. Lisaks ei läbi artiklid enne avaldamist ranget eelretsenseerimist, nagu see on teadusajakirjades tavaks. (Knight \& Pryke, 2012) Sellise demokraatliku töökorralduse tõttu on kirjutajate ja seega artiklite tase varieeruv (Emigh \& Herring, 2005), millega on omakorda seotud teine osa probleemidest. Nimelt kasutavad õppijad oma akadeemilistes töödes Wikipediat esmase teabeallikana (Miller, 2014; Tardy, 2010). Tugeva infovoo tõttu on õppijatel raskusi allikate hindamisega, nt ei tehta vahet eelretsenseeritavatel akadeemilistel tekstidel ja muudel allikatel (Miller, 2014). Halvimal juhul esitavad õppijad Wikipedia artikli osi oma tööde pähe (Tardy, 2010).

Wikipedia vastuoluline olemus ja õppijate eksimused akadeemiliste tavade vastu on kutsunud esile õpetajate ja õppejõudude negatiivse suhtumise Wikipediasse. Õppijatele rõhutatakse, et Wikipedia on ebausaldusväärne ja ebateaduslik (Knight \& Pryke, 2012), mistõttu tuleks sellesse kriitiliselt suhtuda. Äärmuslikel juhtudel väljendub negatiivne suhtumine seisukohas, et Wikipedia kehastab kõike halba, mida internet on akadeemilisele uurimistööle tekitanud (Crovitz \& Smoot, 2009). Wikipediat käsitatakse kui barbarit, võõrast, kes

Kuna Wikipedial põhinevate ülesannete sihtrühma moodustavad nii üldhariduskoolide õpilased kui ka kõrgkoolide üliõpilased, kannavad nad artiklis koondnimetust õppijad. Vaid nendes tekstiosades, kus on vaja eristada üldhariduskooli ja kõrgkooli konteksti, oleme kasutanud vastavalt nimetusi ópilane ja üliópilane. 
ründab akadeemilise maailma elevandiluutorni. Mõnel juhul on see viinud ka Wikipedia täieliku keelustamiseni õppetöös. (Konieczny, 2012)

Võttes arvesse, et Wikipediast on kujunenud üks populaarseimaid veebilehti maailmas, on paratamatu, et õppijad kasutavad seda teadmiste hankimiseks (Konieczny, 2012). Pealegi annab Google esimeste vastete hulgas peaaegu alati Wikipedia kirje, mistõttu on õppijatele tarbetu öelda, et Wikipediast tuleks eemale hoida (Knight \& Pryke, 2012). Sellise arusaama mõjul on vähemalt mõnevõrra mahenenud suhtumine Wikipediasse: leitakse, et Wikipedia keelustamise asemel peaksid nii üldhariduskoolide õpetajad kui ka kõrgkoolide õppejõud hoopis lõikama kasu sellest, et õppijad on Wikipediaga tuttavad (Miller, 2014). Järjest suuremat poolehoidu on leidnud arvamus, et Wikipediat saab edukalt kasutada akadeemilise uurimistöö lähtekohana, sest see võimaldab saada huvialusest teemast kiiret ülevaadet, selgitada välja mõistete tähendusi ja hankida kirjandusviiteid (Knight \& Pryke, 2012). Samuti nähakse Wikipedias üha enam vahendit, mida on võimalik õppetöös tõhusalt rakendada, sest see pakub ainulaadset koostöise kirjutamise võimalust (Fessakis \& Zoumpatianou, 2013).

Siinses artiklis soovime välja selgitada vikiülesande võimalused üliõpilaste akadeemilise kirjaoskuse arengu toetamisel. Tuginedes Tartu Ülikooli väljendusõpetuse kursuste õppejõudude, õppeassistentide ja üliõpilastega tehtud fookusrühma intervjuudele, otsime vastust järgmistele uurimisküsimustele.

1. Millistest töökorralduslikest etappidest koosneb Tartu Ülikooli väljendusõpetuse kursustel kasutatav vikiülesanne?

2. Mis on vikiülesande tugevad küljed?

3. Mis on vikiülesande nõrgad küljed?

4. Milliseid soovitusi annavad fookusrühmad vikiülesande paremaks korraldamiseks?

Järgnevalt teeme teaduskirjanduse põhjal ülevaate Wikipedia kasutamisest õppetöös. Seejuures keskendume akadeemilisele kirjaoskusele ja selle osaoskustele, mida soovitakse eri tüüpi ülesannete kaudu arendada.

\section{Wikipedia õppetöös}

Digikeskkonna tehnilisi lahendusi saab käsitleda kas aknana, mis võimaldab lihtsat ligipääsu teabele, või peeglina, mis nõuab kriitilist mõtlemist ja pidevat refleksiooni. Aknafunktsiooni korral kasutab lugeja Wikipediat pelgalt faktide hankimise kohana, seevastu peeglifunktsiooni korral on ta kaasatud mitmekihilisse teadmusloomesse. Kuna Wikipedia kasulikkus avaldub vaid siis, kui selle sisu arendamisele aidatakse aktiivselt kaasa, mitte ei tarbita seda 
passiivselt, tuleb õppijatele tutvustada Wikipedia aluseks oleva infoedastusprotsessi kihte (artikkel, arutelu, muudatuste tegemine, ajalugu) ning õpetada neid vaatama teksti taha. (Reilly, 2011) Wikipedia kasutamine klassiruumis peaks põhinema metateadlikkusel (Crovitz \& Smoot, 2009), mistõttu lasub õpetajatel ja õppejõududel kohustus õpetada, kuidas Wikipediat vastutustundlikult kasutada (Konieczny, 2012). Selline taotlus on kooskõlas digiajastu pedagoogiliste vajadustega: kui varem oli veeb peamiselt info saamise või vahendamise koht, siis tänapäeval nähakse seda pigem koostöise õpikeskkonnana. Välja on kujunenud uus pedagoogiline paradigma, milles tähtsustatakse tarvidust arendada akadeemilises ja tööelus edukaks toimetulekuks vajalikke oskusi. (Kuteeva, 2011)

Wikipediast kui peeglist lähtuvaid ülesandeid saab kasutada nii üldhariduskui ka kõrgkooli aine- ja keeleõppes. Olenemata õppeastmest tuleb õppijad viia esmalt kurssi vikiartikli kui tekstiliigi tavadega. Näiteks võib pakkuda neile ülesandeid, kus tuleb artikleid mingite tunnuste alusel klassifitseerida ja võrrelda või kirjutada kas ühe või mitme artikli kohta retsensioon (Fessakis \& Zoumpatianou, 2013). Seejärel saab edasi minna ülesannetega, mis nõuavad artikli täiendamist või uue artikli kirjutamist. Üldhariduskoolis soovitatakse alustada väikeste sammudega ehk parandada või täiendada olemasolevaid artikleid (Crovitz \& Smoot, 2009; Fessakis \& Zoumpatianou, 2013; Tardy, 2010). Niisamuti võib uue artikli loomine olla raske täiskasvanutele, kes pole Wikipediasse varem kirjutanud, mistõttu võiks neilgi lasta täiendada olemasolevaid artikleid, eeskätt selliseid, mis koosnevad peaasjalikult vaid märksõnast ja definitsioonist, sest nende artiklite vajalikkuse on Wikipedia kogukond juba heaks kiitnud (Reilly, 2011). Kui aga anda õppijatele ülesandeks kirjutada uus artikkel, on soovitatav jagada ülesanne osadeks ja pakkuda õppetöö vältel neile piisavat tuge (ülesande kirjeldust vt nt Konieczny, 2012; Tardy, 2010). Järelülesandena saab lasta õppijatel vaadata üle muudatused, mida on Wikipedia kogukond nende artiklites teinud, ja kirjutada nende muudatuste kohta kokkuvõte (Fessakis \& Zoumpatianou, 2013; Reilly, 2011).

Eelkirjeldatud, aga ka muud Wikipedia-põhised ülesanded, kus õppijad ei ole pelgalt lugeja rollis, toetavad akadeemilise kirjaoskuse arengut. Kuigi akadeemilist kirjaoskust samastatakse mõnikord akadeemilise teksti kirjutamise oskusega, ei seisne kirjaoskus üksnes kirjutamisoskuses: akadeemiline kirjaoskus väljendab suutlikkust akadeemilises ringkonnas pädevalt suhelda, mis omakorda eeldab oskust lugeda, teavet kriitiliselt hinnata ja esitada ning teadmisi luua, seda nii kirjalikult kui ka suuliselt (Wingate, 2018). Peale verbaalsete elementide hõlmab akadeemiline kirjaoskus ka mitteverbaalseid osi, nt fotosid ja graafikuid (Richards \& Pilcher, 2018). Kuna sellisel kujul ei ole akadeemiline kirjaoskus üksikoskus, vaid oskuste kogum, soovitavad Mary Lea 
ja Brian Street vaadelda seda kirjutamisõpetuse kontekstis kolmetasandilisena. Esimese tasandi moodustavad õpioskused (study skills), mis tuleb mehaaniliselt omandada ja mida saab teise konteksti üle kanda, nt õigekiri. Teisele tasandile kuulub akadeemiline sotsialiseerimine (academic socialisation), mille korral viiakse üliõpilane kurssi akadeemilise kultuuri tavadega, et toetada tema sügavat õppimist. Kolmanda ehk kõrgeima tasandi moodustab akadeemiline kirjaoskus (academic literacies), mis nõuab suhtlusolukorras osalejate identiteedi ja seega võimusuhetega seotud sotsiaalsete tavade tundmist ning pidevat kohandamist. Seejuures hõlmab akadeemiline kirjaoskus kui laiem mõiste nii õpioskusi kui ka akadeemilist sotsialiseerimist, võimaldades vaadelda kirjutamist üldises institutsioonilises kontekstis. (Lea \& Street, 1998)

Vikiartikli kirjutamise ülesanne on nõudlik, sest õpetaja või õppejõud peab tegelema eri tasanditega. Et õpetamine oleks tõhus, tuleks alustada kõrgeimast ehk akadeemilise kirjaoskuse tasandist, mis eeldab, et õpetaja või õppejõud ise tunneb Wikipeedia toimimise mehhanisme, sh kogukondlikku rollijaotust. Ka Piotr Konieczny (2012) rõhutab tabavalt, et juhendaja, kes ei ole Wikipedia artiklit kirjutanud, on õpetamisel sama vähe tõhus kui see, kes annab mingi raamatu kasutamiseks juhiseid, ilma et ta oleks selle ise läbi lugenud. Kui õpetaja või õppejõud on Wikipediaga tuttav, saab ta koos õppijatega arutleda vikitehnoloogia olemuse üle ja seejärel anda neile väikseid ülesandeid (nt linkide lisamine, teabe ajakohastamine), et neil tekiks veebientsüklopeediast kui žanrist esmane ülevaade (Crovitz \& Smoot, 2009). Sel viisil sotsialiseeritud õppijatele on võimalik anda ülesandeid, mis arendavad nende õpioskusi, sealhulgas järgmisi ülekantavaid oskusi.

- Digipädevus. Kuigi arvatakse, et tänapäeva õppijad tulevad tehnika ja tehnoloogiaga hõlpsalt toime, ei ole see sageli nii (Miller, 2014). Wikipedia pakub õppijatele võimalust omandada lihtsaid tekstitöötlusoskusi, osaleda koostöise kirjutamise protsessis ja veebikogukonna tegevuses (Fessakis \& Zoumpatianou, 2013).

- Infopädevus. Kuna Wikipedia on referatiivne allikas, saab vikiülesande kaudu lasta õppijatel hinnata kasutatavate allikate usaldusväärsust, võrrelda eri allikaid, otsida infot ning vormistada viiteid ja allikakirjeid (Oliver, 2015). Kui juhtida õppijate tähelepanu sellele, et ka vikiartikkel ise on referaat ehk kellegi kokkuvõte mingitest allikatest, võimaldab see suurendada õppijate teadlikkust, miks Wikipediat ennast ei sobi refereerida (Zupping \& Noorma, 2018, lk 280).

- Uurimis- ja analüüsioskus. Vikiülesanne aitab parandada uurimistöö kirjutamise oskust, sest Wikipediasse kirjutamine meenutab päris maailma uurimisprotsessi: esmalt tuleb valida teema, seejärel tuvastada teadmiste lünk, koostada kavand, teha uurimistööd, kirjutada tekst valmis ja avaldada 
see lõplikul kujul (Dawe \& Robinson, 2017). Wikipedia artiklit kirjutades tunnevad õppijad end päris teadlastena (Crovitz \& Smoot, 2009).

- Kirjutamisoskus. Wikipedia võimaldab suurendada õppijate teadlikkust entsüklopeediaartiklist kui tekstiliigist ning arendada artiklite täiendamise ja kirjutamise kaudu nende kirjutamisoskust. Vikiülesandega saab juhtida õppijate tähelepanu nii tervikteksti loomisele, lõigu ülesehitusele, lauseehitusele, sõnavalikule kui ka ortograafiaküsimustele. Peale emakeeleõppe pakub Wikipedia mitmesuguseid võimalusi võõrkeeleõppeks, nt õppijad võivad võrrelda ema- ja võõrkeeles kirjutatud artikleid ning kirjutada võõrkeelseid artikleid (Fessakis \& Zoumpatianou, 2013).

- Kriitiline mõtlemine. Selle asemel et suunata õppijaid Wikipediast eemale, tuleb arendada nende kriitilist mõtlemist (Reilly, 2011), tutvustades neile Wikipedia osaluspõhist olemust, kaasates neid artiklite loomisse ja/või hindamisse ning soodustades nende osalemist sisukates aruteludes.

- Koostööoskus. Koostöö Wikipedia keskkonnas toimub eri tasanditel. Koostöise kirjutamise korral tehakse tekstis korduvalt parandusi, arutletakse sisu üle, edastatakse teavet ja jagatakse ära tööülesanded (Fessakis \& Zoumpatianou, 2013). Wikipedia kogukonnas osaledes vahetavad üliõpilased mõtteid teiste autorite-toimetajatega ja saavad enda kaastöö kohta tagasisidet (Reilly, 2011).

Vikiülesande väärtus seisneb selle mitmekülgsuses. Tervikülesande ehk olemasoleva artikli täiendamise või uue artikli loomise kaudu saab arendada mitmesuguseid, sh kõrgema tasandi oskusi. Sagedasimad õpiväljundid on seotud kriitilise mõtlemise, koostöö-, digi- ja infopädevuse ning uurimis- ja analüüsioskusega, mis väljendavad ühtlasi tänapäevase haridussüsteemi põhiväärtusi (Fessakis \& Zoumpatianou, 2013). Kuna enamik vikiülesandeid ei ole erialaspetsiifilised, sobivad need erialaüleseks kasutuseks, luues hea võimaluse lõimitud aine- ja keeleõppeks. Samuti esindavad õppijatele antavad ülesanded õppijakeskset õpetamist ning on seega kooskõlas sotsiaalkonstruktivistliku õpikäsitusega (Fessakis \& Zoumpatianou, 2013).

Peale mitmekülgsuse väärtustatakse vikiülesannet ka selle autentsuse pärast. Andrea Forte ja Amy Bruckman rõhutavad, et tavaliselt antakse õppijatele selliseid kirjutamisülesandeid, mis on väljaspool klassiruumi ebaolulised, kuid vikiartikli jaoks saavad óppijad valida teema, mis neid huvitab, ja avaldada oma töö veebis, mis loob seose päris maailmaga. Just auditooriumi tunnetamine on kirjaliku suhtluse tähtis osa, sest see muudab õpikogemuse tähenduslikumaks. (Forte \& Bruckman, 2006) Enda jaoks tähenduslikke vikiartikleid kirjutades tegutsevad õppijad motiveeritumalt, mis ilmneb näiteks selles, et artiklid on ettenähtust pikemad ja sisaldavad rohkem allikaid (Dawe \& Robinson, 2017). Samuti on õppijad näidanud üles valmisolekut tegelda oma vikiartikliga edasi 
väljaspool klassiruumi või luua vabatahtlikult uusi artikleid, mis on märk kaasatusest ja elukestva õppe valmidusest (Pollard, 2008). Kuigi kirjutamist laiale veebikogukonnale peetakse üldjuhul heaks intellektuaalseks stiimuliks, tuleb arvestada sellega, et Wikipedia-põhine ülesanne võib olla osa õppijate jaoks heidutav (Miller, 2014), sest nad tunnevad suurt vastutust oma kirjutatu eest, mistõttu vajavad nad õpetaja või õppejõu igakülgset toetust.

Järgnevalt anname ülevaate Tartu Ülikoolis õpetatavate väljendusõpetuse kursuste ainekavast, sealhulgas kirjeldame vikiülesande osa selles.

\section{Vikiülesanne Tartu Ülikooli väljendusõpetuse kursustel}

Eesti keelt on kohustusliku ainena õpetatud osal Tartu Ülikooli erialadel sõjaeelse Eesti vabariigi aegadest saati ja ka nõukogude ajal. Taasiseseisvunud Eestis hakati kõrgkoolis õppijate eesti keele oskusele eritähelepanu pöörama 2000. aastate alguses, mil mindi üle Bologna süsteemile ja muude pädevusvaldkondade kõrval tõusis fookusse keelepädevus. Selle tulemusena muudeti väljendusõpetuse kursus 2002. aastast kohustuslikuks kõigile Tartu Ülikooli humanitaarerialade üliõpilastele ning kolm aastat hiljem, 2005. aastal ka kõigi muude erialade üliõpilastele. Sellist muudatust toetasid nii ülikoolisisesed dokumendid, nt Tartu Ülikooli nõukogu 2005. aasta otsus teaduskeele edendamise kohta, mille üks põhisuundi oli väljendusõpetuse kursuse arendamine, kui ka riiklikud dokumendid, nt eesti keele arengukava aastateks 2011-2017, kus rõhutati vajadust tõhustada eesti erialakeele ja akadeemilise väljendusoskuse õpetamist. (Klaas-Lang, 2012) Sellest hoolimata ei toonud see muudatus kõigile üliõpilastele kaasa kohustust võtta väljendusõpetuse kursust, sest mõnel erialal kuulub see valikainete hulka. Küll aga muutub eesti keele suulist ja kirjalikku eneseväljendust arendav õppeaine vähemalt $3 \mathrm{EAP}$ mahus kohustuslikuks kõigile bakalaureuseõppekavade ning bakalaureuse- ja magistriõppe integreeritud õppekavade üliópilastele alates 2020/2021. õppeaastast (Õppekava statuut, 2018).

Teisenenud olud on tinginud vajaduse väljendusõpetuse ainete sisu ja õppemeetodite muutmise järele. Sel eesmärgil on eesti ja üldkeeleteaduse instituudi õpetatavad üleülikoolilised väljendusõpetuse ainekursused läbinud 2016.-2017. aastal Tartu Ülikooli arengufondi toel põhjaliku reformi. Välja on töötatud uus ainekava, mis hõlmab nelja moodulit: erialast eesti keelt, akadeemilist teksti, akadeemilist ettekannet ja tarbeteksti. Kursuse keskmes on kirjutamisülesanne, mis tugineb protsessikeskse tekstiloome põhimõtetele (vt Jürine, Leijen, \& Tragel, 2017; Jürine \& Tragel, 2018). Võimaluse korral seotakse see ülesanne mõne erialaaine kirjaliku tööga, nt essee või referaadiga, 
kuid kui see ei ole võimalik, on osa õppejõude valinud kirjutatavaks tekstiks Vikipeedia artikli. Nii on vikiülesannet kasutatud 2011. aastast aines „Eesti keele suulise ja kirjaliku väljenduse õpetus“, mida õpetatakse praeguse loodusja täppisteaduste valdkonna üliõpilastele, ent eri variantides on see jõudnud ka ainetesse „Akadeemiline eesti keel“, „Eestikeelne kommunikatsioon arvutiteaduses“ ning „Eesti õigekeelsus ja väljendusõpetus“ (vt tabel). Nendes ühe semestri vältavates ja 3 EAPd andvates ainetes on üliõpilased kirjutanud ligi 2000 vikiartiklit, enamasti oma erialaga seotud teemadel.

Tabel. Ülevaade vikiülesande kasutamisest ainete kaupa

\begin{tabular}{|c|c|c|c|}
\hline Ained & Erialad & Aastast & Artikleid* \\
\hline $\begin{array}{l}\text { „Eesti keele suulise ja } \\
\text { kirjaliku väljenduse } \\
\text { õpetus" (LO00.00.003) }\end{array}$ & $\begin{array}{l}\text { Arvutitehnika } \\
\text { Bioloogia ja elustiku kaitse } \\
\text { Füüsika } \\
\text { Geenitehnoloogia } \\
\text { Geograafia } \\
\text { Geoloogia ja keskkonnatehnoloogia } \\
\text { Keemia } \\
\text { Ökoloogia ning elustiku kaitse }\end{array}$ & 2011 & 1577 \\
\hline $\begin{array}{l}\text { "Akadeemiline eesti } \\
\text { keel“ (HVEE.01.004) }\end{array}$ & $\begin{array}{l}\text { Eripedagoogika } \\
\text { Filosoofia ja semiootika } \\
\text { Romanistika } \\
\text { Kirjandus- ja teatriteadus }\end{array}$ & 2017 & 81 \\
\hline $\begin{array}{l}\text { "Eestikeelne } \\
\text { kommunikatsioon } \\
\text { arvutiteaduses" } \\
\text { (MTAT.06.041) }\end{array}$ & $\begin{array}{l}\text { Matemaatika } \\
\text { Matemaatiline statistika } \\
\text { Informaatika }\end{array}$ & 2017 & 201 \\
\hline $\begin{array}{l}\text { "Eesti õigekeelsus } \\
\text { ja väljendusõpetus" } \\
\text { (FLEE.02.042) }\end{array}$ & $\begin{array}{l}\text { Õigusteadus } \\
\text { Kutseõpetaja }\end{array}$ & 2018 & 48 \\
\hline $\begin{array}{l}\text { „Eesti õigekeelsus } \\
\text { ja väljendusõpetus" } \\
\text { (P2PC.00.507) }\end{array}$ & $\begin{array}{l}\text { Ettevõtlus ja projektijuhtimine } \\
\text { Turismi- ja hotelliettevõtlus } \\
\text { Sotsiaaltöö ja rehabilitatsiooni korraldus }\end{array}$ & 2018 & 60 \\
\hline
\end{tabular}

Märkus. * - andmed seisuga 1. jaanuar 2019.

Vikiülesande on lisanud oma väljendusõpetuse kursuse programmi kaheksa õppejõudu, kes küll õpetavad eri aineid ja eri erialade üliõpilasi, kuid kes osalevad väljendusõpetuse kursuse arendamise kogemuskogukonna tegevuses ning pakuvad seega üksteisele kollegiaalset tuge. Kuigi ülesande põhialused on omavahel kokku lepitud, on óppejõududele antud vabad käed, kuidas oma aines seda ülesannet korraldada. Peale isiklike eelistuste võetakse ülesande 
korraldamisel arvesse nii õppevormist (päeva- või sessioonõpe), õppeaastast (1., 2. või 3. õppeaasta) kui ka erialast tulenevaid vajadusi. Samuti oleneb töökorraldus õpetatava rühma suurusest ja rühmade arvust ühe õppejõu kohta. Näiteks need õppejõud, kes õpetavad korraga mitut väikest, u 30 üliópilasega rühma või kel on ühes rühmas üle saja õppija, on kaasanud õppetöösse ka õppeassistendid (enamasti eesti keele eriala üliõpilased), kes on abiks artiklite tagasisidestamisel, kuid kelle täpsemad tööülesanded lepitakse iga kord eraldi kokku.

Et selgitada välja, kuidas õppejõud kasutavad vikiülesannet õppetöös ning millised on selle ülesande tugevad ja nõrgad küljed, ning leida viise, kuidas ülesannet edasi arendada, tegime fookusrühma intervjuud nii väljendusõpetuse kursuste õppejõudude, õppeassistentide kui ka üliõpilastega. Järgnevalt on esitatud kokkuvõte uuringu lähtekohtadest ja tulemustest.

\section{Ülevaade uuringust}

\section{Andmekogumine}

Uuring põhineb fookusrühma intervjuudel, mis on tehtud väljendusõpetuse kursuste õppejõudude, õppeassistentide ja üliõpilastega. Fookusrühma intervjuu kui kvalitatiivne andmekogumismeetod võimaldab interaktiivse arutelu kaudu koguda osalejate arvamusi huvialuse teema kohta (Hennink \& Leavy, 2013, lk 1). Eesmärk ei ole lahendada mõnd probleemi või saavutada mingis küsimuses üksmeelt (Patton, 2002, lk 385-386), vaid pakkuda osalejatele võimalust jagada oma seisukohti või kogemusi teistega ning jõuda sünergia kaudu detailse, sügava aruteluni (Hennink \& Leavy, 2013, lk 3). Et arutelu oleks fookustatud ehk püsiks uurimiseesmärgi seisukohalt olulistel teemadel, otsustasime poolstruktureeritud intervjuu kasuks. Intervjuukava sisaldas nelja põhiküsimust vikiülesande korralduse, tugevate ja nõrkade külgede ning edasiste soovituste kohta, kuid võimaldas ka teatavat paindlikkust, nt esitada osalejatele või lasta osalejatel esitada üksteisele täpsustavaid küsimusi. Intervjuu algas lihtsama kirjeldava faktiküsimusega ning jätkus analüüsimis- ja sünteesimisoskusi nõudvate keerukamate küsimustega.

Uuringu valimisse kuuluvad väljendusõpetuse kursuste õppejõud $(n=5)$, kes on kasutanud oma kursustel vikiülesannet, ning nende õppeassistendid $(n=$ 6) ja üliõpilased $(n=7)$. Osalejate valimisel järgisime eesmärgipärase valimi moodustamise põhimõtteid, mille kohaselt tuleb uuringusse kaasata sellised sihtrühma esindajad, kes on huvialuse teemaga hästi kursis ning kel on aega ja tahtmist uuringus osaleda ning oma kogemusi ja arvamusi teistega jagada (Etikan, Musa, \& Alkassim, 2016). Sellistelt intervjueeritavatelt on võimalik 
koguda rikkalikke kirjeldusi ja seeläbi käsitleda uurimiseesmärgi seisukohalt olulisi teemasid sügavuti (Patton, 2002). Kuigi üldjuhul soovitatakse valim komplekteerida osalejatest, kes üksteist eriti ei tunne (Õunapuu, 2014), polnud seda soovitust siinkohal võimalik järgida, sest praegune uurimus kuulub oma õpetamise uurimise valdkonda, mistôttu on meie seotus uuritavatega ja uuritavate omavaheline seotus paratamatu. Vaid üliõpilaste fookusrühma moodustamisel jälgisime, et osalejad esindaksid võimaluse korral eri erialasid ja kuuluksid eri õppejõudude rühmadesse, sest tahtsime saada ülesande korraldusest võimalikult laia ülevaadet.

Kõik kolm rühmaintervjuud tehti artikli esimese autori juhatamisel Tartu Ülikooli eesti ja üldkeeleteaduse instituudi seminariruumis vahemikus detsember 2018 - jaanuar 2019. Iga intervjuu algas uuringu eesmärgi kirjeldamise ja eetikanõuete tutvustamisega (konfidentsiaalsus, nõusolek, teave intervjuude analüüsimise ja tulemuste avaldamise kohta). Intervjuud kestsid 90-120 minutit, need helisalvestati ja transkribeeriti. Transkribeeritud tekstide kogupikkus on 101 standardlehekülge.

\section{Andmeanaliüis}

Kogutud andmete analüüsimisel lähtusime kvalitatiivse sisuanalüüsi põhimõtetest. Mayringi (2000) sõnul on kvalitatiivne sisuanalüüs metoodiliselt juhitud empiiriline viis analüüsida tekste nende suhtluskontekstis. See tähendab, et tekst moodustab küll esmase sisutasandi, kuid peale teksti tuleb arvesse võtta ka konteksti kui teisest tasandit. Nii ei piirdu kvalitatiivne sisuanalüüs üksnes ilmnenud tekstimustrite kirjeldamisega, vaid see lisab analüüsile sügavust, võimaldades nende mustrite esinemust ka põhjendada - huvi keskmesse on seatud küsimused miks? ja kuidas? (Morgan, 1993). Kvalitatiivse sisuanalüüsi kaudu saab seega uurida uusi teemasid, kirjeldada keerulisi nähtusi, võrrelda ja vastandada rühmade erinevusi ning arendada ja katsetada teooriaid (Drisko \& Maschi, 2016, lk 86).

Kvalitatiivse sisuanalüüsi raamistikus lähenesime andmetele induktiivselt ehk piiritlesime teksti põhjal tähendusüksused (vt analüüsiprotsessi kirjeldust Mayring, 2000). Kõigepealt lugesid siinse artikli teine ja kolmas autor kõik transkriptsioonid läbi, et saada sisust ülevaade. Seejärel võtsid nad aluseks uurimisküsimused ja kodeerisid transkriptsioonides olevad andmed. Järgmises etapis vaadati kodeeringud koos üle: neid kõrvutati ning vajaduse korral täiendati ja täpsustati. Analüüsi viimases etapis moodustasid kodeerijad tekstilähedaste koodide põhjal üldisemad kategooriad, nt „töökorraldus“ („tagasiside“, „õppeassistentide ülesanded“); „ülesande tugevad küljed“ („motivatsioon“, „akadeemiline kirjaoskus“, „,erialateadmised“); „ülesandega seotud 
probleemid“ („ajaplaneerimine“, „tõlkimine“, „terminoloogia“, „viitamine“). Nendel kategooriatel põhinevad ühtlasi järgmises peatükis esitatud uurimistulemused.

\section{Tulemused}

Väljendusõpetuse ainekava võimaldab õppejõududel üldisi teemamooduleid järgides valida, mis kirjutamisülesandeid kursusel kasutada. Siinses uuringus osalenud õppejõud on kasutanud vikiartikli ülesannet, sest see võimaldab luua autentset ehk päriselulist erialast teksti, mille kaudu õpitakse teadusteavet otsima, allikaid kriitiliselt hindama, refereerima, sünteesima ja viitama ning teksti viimistlema. Järgnevalt teeme ülevaate ülesande korraldusest ning selle tugevatest ja nõrkadest külgedest nii õppejõudude, õppeassistentide kui ka üliõpilaste vaatenurgast, samuti esitame soovitusi selle kohta, mida võiks vikiartikli ülesande juures edaspidi arvesse võtta. Tulemusi ilmestavad intervjuukatked, mida oleme parema loetavuse huvides vähesel määral toimetanud.

\section{Ülesande korraldus}

Õppetöös kirjutatav Vikipeedia artikkel on erialane referatiivne tekst, mis põhineb algallikatel, kuid infot võidakse ammutada ka võõrkeelsete vikipeediate samasisulistest artiklitest. Enamasti kirjutatakse kursusel uus eestikeelne artikkel, kuid kui valitud teema kohta on Vikipeedias artikkel juba olemas, siis üliõpilased täiendavad seda. Kuigi vikiartikli ülesannet on kursuseti korraldatud mõnevõrra erinevalt, joonistuvad siiski välja mõningad ühised tunnused: esimeses etapis keskendutakse teemavalikule, ülesande korraldamisel lähtutakse protsessikeskse tekstiloome põhimõtetest, üliõpilaste kirjutatud tekstile antakse individuaalset tagasisidet ja neile pakutakse enne lõplikku hindamist võimalust tagasiside põhjal tekstis parandusi teha.

Intervjuul osalenud õppejõud kirjeldasid seitset viisi, kuidas ülesannet korraldada. Laias laastus jaguneb vikiülesanne kuueks etapiks: 1) Vikipeedia olemuse tutvustus, teemavalik ja infootsing, 2) esimene mustand, 3) tagasiside, 4) puhtand, 5) tagasiside ja 6) artikli avaldamine Vikipeedia põhiruumis. Korralduslikud erinevused ilmnevad selles, kui palju aega pühendatakse teemavalikule, kuhu kirjutatakse mustandid (tekstidokument või Vikipeedia keskkond), kes annab teksti kohta tagasisidet (kaasõppijad, õppeassistent või õppejõud) ning kuidas toetatakse teksti vormistamist (vikiseminar või videojuhend). Fookusrühma aruteludes märkisid õppejõud, et nad mõtlevad pidevalt sellele, mida ülesande korralduses võiks muuta, ja ei lähtu alati varasemast, juba läbi proovitud vormist. 
Nii nagu on tervikülesanne mõnevõrra erinevalt üles ehitatud, varieerub ka tagasiside andmise korralduslik pool. Fookusrühma intervjuudest ilmnes, et mõne rühma üliõpilased saavad tekstile rohkem kui kolm korda tagasisidet, kuid mõni rühm saab tagasisidet korra või kaks. See oleneb paljuski rühma suurusest, võimalusest kaasata tagasisidestamisse õppeassistente ja sellest, kas üliõpilased on koondatud kirjutamisrühmadesse.

Siis kogunesime kolme kaupa rühmadesse, kus me siis - Moodle’i keskkonnas käis meil see töö - oma rühma foorumisse laadisid oma töö üles. Siis oli mingi aeg üksteisele tagasiside andmiseks. Et täiesti põhjalikult käisime läbi veel kahe kaaslase tööd. Ja pärast seda vaatas meie mustandid läbi õppeassistent, kes andis kirjalikku tagasisidet, ja ta vaatas ka üksteisele antud tagasisidet. Siis tegime omakorda parandused ja endiselt Wordi failina sinna Moodle'isse. Esitasime puhtandi, millele saime õppejõult videotagasisidet. Väga põhjaliku, see oli väga põhjalik. Ja siis, kes soovis, laadis selle [artikli] päriselt üles. (Üliõpilane_E)

Kõigi fookusrühma intervjuude analüüsi põhjal saab väita, et tagasisidestamine on ülesande olulisim osa. Kuna väljendusõpetuse ainete õpiväljundid on seotud tekstiloome, õigekeelsuse, refereerimise ja viitamisega, siis neile oskustele tagasisidestamisel tähelepanu pöörataksegi. Suuremates õpperühmades on tagasisidestamisel abiks õppeassistendid, väiksemates rühmades tagasisidestavad tekste õppejõud ise. Olenevalt õppejõu eelistustest antakse üliõpilastele kas koondtagasisidet (tabel tüüpvigade ja lahendustega), individuaalset tagasisidet tekstifailis või Vikipeedia alamlehel või videotagasisidet (ekraanijälgimise funktsiooniga).

Õppeassistentide täpsemad ülesanded olenevad sellest, kuidas on vikiartikli ülesanne tervikuna korraldatud. Olenemata korraldusest ei piirdu tagasiside andmine siiski vaid keelekasutuse kommenteerimisega. Näiteks tuleb refereeringu korrektsuse üle otsustamisel ka sisusse süüvida.

Minu meelest need ülesanded on meil erinevad olnud erinevate ainete raames. Et osades ainetes ongi selline ülesanne, et me peame väga täpselt kirjutama tudengile, mida ta parandama peab, mõnedes ainetes on olnud meil endal luba väiksemad parandused ise ära teha, et mitte tudengeile kommentaari kirjutada. Ühes aines oli meie esmane ülesanne panna hoopis kirja kõik põhilised vead ühisesse dokumenti, mis siis saadeti tudengitele edasi, ja nad pidid ise oma artikleid vaatama. (Õppeassistent_A)

Õppejõudude hinnangul on suuremate rühmade õpetamisel õppeassistentide tugi väga vajalik, sest nii saab anda üliõpilastele kiirelt tagasisidet. Samuti toovad õppejõud esile, et õppeassistendid on aidanud neil ülesannet välja töötada. 
Ühtlasi saavad assistendid seda tööd tehes keeletoimetamis- ja õpetamiskogemuse. Ka intervjuul osalenud assistendid rõhutasid, et nende jaoks on oluline koguda erialase töö kogemust juba õpingute ajal. Samuti pidasid nii õppeassistendid kui ka õppejõud tähtsaks, et õppeassistendi töö eest makstaks tasu.

Kuigi enamik meist on tudengid, siis me saame tunda isegi selles rollis, oleme nagu mingil alal oleme natuke spetsialistid ja saame kellelegi nõu anda, see tekitab mingis mõttes hea tunde ikkagi ... Noh, kuigi me ei ole ju mingid spetsialistid päriselt, aga et me oskame näha juba mingeid asju ja öelda, et kuule, et siin peaks ikkagi nii olema. Et see tekitab ka mingi hea tunde. (Õppeassistent_C)

Tagasiside andmine ja selle põhjal paranduste tegemine on üks osa protsessikesksest tekstiloomest. Üliõpilased mainisid, et mustandi kohta antud individuaalne tagasiside oli väga tõhus, sest see julgustas oma vigu parandama ja edasi kirjutama. Üliõpilaste jaoks oli kasulik saada mitu korda tagasisidet ja seeläbi mõista, et akadeemilise teksti loomine nõuab aega ja kõrvalpilku.

Mulle oli kasulik see oma valitud teema hästi läbimõtlemine ja selline mitmekordse tagasiside põhjal ikka järjest paremaks tegemine. (Üliõpilane_D)

Tagasisidestamise puhul oli see, et see oli nagu antud sellises positiivses võtmes, et see ei tekitanud sul tunnet, et sa ei taha sellega edasi minna või edasi kirjutada. (Üliõpilane_C)

Eeltoodu põhjal võib kokkuvõtvalt väita, et kõigi fookusrühmade esindajad tähtsustavad tagasiside rolli õpiprotsessis. Seejuures ei mõjuta tagasiside ja ülesande kui terviku väärtust üliõpilaste silmis see, mitu korda, mis vormis ja kellelt nad tagasisidet saavad.

\section{Ülesande tugevad küljed}

Fookusrühma intervjuude analüüsist ilmneb, et Vikipeedia artikli kirjutamise ülesande tugevad küljed võib üldjoontes jagada kolme rühma: akadeemiline kirjaoskus, erialateadmised ja motivatsioon. Neid kategooriaid kirjeldame alljärgnevalt eelkõige sellest seisukohast, mis kasu ülesanne õppijatele pakub.

Õppejõudude hinnangul arendab vikiülesanne akadeemilist kirjaoskust ehk õpetab erialast materjali otsima, allikakriitiliselt ja süvenenult lugema, nõuetekohaselt refereerima ja viitama (sh eri viitesüsteeme rakendama) ning allikaid sünteesima. Ühtlasi saab refereerimis- ja viitamisvõtete kaudu õpetada 
plagiaadist hoidumist. Ka üliõpilaste sõnul on vikiülesanne hea harjutus, kuidas akadeemiliselt korrektselt kirjutada, sest paljusid võtteid saab rakendada lõputöö kirjutamisel.

Ja minu meelest see ülesanne andis neile võimaluse harjutada akadeemilise teksti loomist: kuidas viidata, kuidas see tekst üldse kokku panna, kuidas selle jaoks on vaja materjali korjata ja võimalusel tagasisidet saada isiklikult oma tekstile. (Õppejõud_E)

Tegelikult ma seda Vikipeedia teksti kirjutades sain alles aru, et mis see akadeemiline kirjaviis siis on. Et kus ma pean reaalselt viitama ära ka suhteliselt elementaarsed asjad, et ikkagi see info põhineb millelgi, mitte ei ole niisama minu arvamus või see, mis ma loengus kuulsin. Et see avas nagu mu silmad. (Üliõpilane_F)

Kuna õppetöö käigus antakse teksti kohta enamasti mitu korda tagasisidet ja ka üliõpilasi suunatakse enda teksti parandama, siis saab vikiülesande kaudu juhtida üliõpilaste tähelepanu nende tüüpilistele õigekirjavigadele, õpetada keelehooldeallikate kasutust ja juhendada neid end selgelt väljendama. Õppejõudude sõnul on vikiülesandesse väga hästi võimalik põimida väljendusõpetuse keskseid õigekirjateemasid.

See Vikipeedia artikkel aitab ka seal kursusel õpitud keelekasutust praktiseerida ja tegelikult, kui sa pärast nagu kirjutad, sa mõtled kogu aeg tegelikult selle peale, et kuidas kirjutada, mis sõnastust ja et see nagu aitas seda kinnistada ja praktiseerida ja mõelda selle peale rohkem. (Üliõpilane_C)

Kuna Vikipeedia artikkel kirjutatakse enamasti erialasel teemal ja selleks on vaja lugeda erialaseid tekste, toetab vikiülesanne õppejõudude taotlust muuta aine erialakeskseks. Õppejõudude ja õppeassistentide hinnangul on vikiülesanne kolmanda aasta üliõpilaste jaoks kasulik muu hulgas seetõttu, et see loob hea võimaluse oma lõputöös kasutatavad põhimõisted endale korralikult selgeks teha.

Kirjutavad artiklit, mis on neile endale ka huvitav või nagu nende enda tööga seotud. Minu meelest nad saavad väga palju kasu sellest, et töötavad mingisuguse mõiste täiesti läbi enda jaoks ja loodetavasti saavad ka sellest aru. (Õppeassistent_A)

Pidades silmas, et Vikipeedia artikkel on avalik tekst, rõhutavad nii õppejõud, õppeassistendid kui ka üliõpilased kirjutamisega kaasnevat vastutust. Ühtlasi mainitakse, et üldjuhul on üliõpilaste motivatsioon kirjutada avalikku teksti suurem kui selliste traditsiooniliste tekstide puhul, mis jäävad vaid õppejõule. 
Fookusrühma intervjuudes osalenud toonitasid, et ülesanne pakub üliõpilastele tähenduslikku õpikogemust - võimalust kirjutada laiale auditooriumile teemal, mis on kirjutaja enda jaoks huvitav.

Aga mulle just meeldib see idee, et tegelikult, kui ma oleks selle suvalisel teemal teinud, siis see oleks jäänud mulle arvutisse dokumendina, aga nüüd see on tegelikult internetiavarustes kõigile kasutada ja tegelikult nii on rohkem võimalik eestikeelset infot internetist leida. (Üliõpilane_D)

Mulle tundub, et seda ülesannet tehes üliõpilased tunnevad ennast õppimises motiveerituna ja tunnevad ennast akadeemilise kogukonna liikmena või oma eriala esindajana. /---/ Vastutuse tunnetamine - ma ei kirjuta mitte óppejõule ja ma ei kirjuta vaid paarile lugejale, vaid see on täiesti avalik tekst eesti rahva ees. (Õppejõud_E)

Vikiartikli ülesanne katab kolme ainekava teemamoodulit - erialast eesti keelt, akadeemilist teksti ja tarbeteksti -, mistõttu peavad õppejõud seda kursuse õpiväljundite saavutamise seisukohalt heaks ülesandeks. Kuigi fookus on akadeemilisel kirjaoskusel, saab ülesande kaudu edendada ka erialakeelt ja suurendada üliõpilaste kirjutamismotivatsiooni. N-ö sahtlisse kirjutamise asemel väärtustavad kõigi fookusrühmade esindajad võimalust kirjutada suurele lugejaskonnale - avalikkusele.

\section{Ülesande nõrgad küljed ja soovitused}

Kuigi fookusrühma intervjuudest selgub, et vikiülesanne on hea vahend, mille abil õpetada akadeemilise teksti kirjutamist, toovad osalised esile ka ülesande puudusi. Enamasti on need seotud tõlkimisest ja terminivalikust tulenevate raskustega, kuid ka eelarvamusega ülesande keerukuse kohta.

Paradoksaalselt valmistab vaatlusaluses kirjutamisülesandes raskusi Vikipeedias muidu nii levinud tava tõlkida artikleid teiste keelte vikipeediatest. Üliõpilased mainisid, et neis tekitab segadust, kas ja kuidas tohivad nad oma eestikeelse artikli kirjutamisel kasutada võõrkeelseid vikiartikleid. Seevastu õppejõud tõdesid, et kui tahta õpetada refereerimist ja allikate sünteesimist, siis peaks vältima võõrkeelse vikiartikli tõlkimist eesti keelde, sest pelk tõlkimine soovitud oskuste omandamist ei toeta.

Mina olen kasutanud seda Vikipeedia artikli kirjutamise harjutust just selleks, et õppida või õpetada refereerimiste viitamist, ja kui nad lihtsalt tõlgivad selle artikli ära, siis neil ei ole võimalust seda ise teha. (Õppejõud_K)

Fookusrühma intervjuus arutasid üliõpilased omavahel ka seda, et terminite kasutamine võib tekitada mõningaid raskusi. Näiteks on keerulised olukorrad, 
kus tuleb otsustada, kuidas termineid tõlkida või milline termin valida, kui võimalikke variante on mitu. See probleem võib ilmneda ka teistes tekstides, mida õppetöös kirjutatakse, kuid kuna Vikipeedia artiklid on avalikud, tunnetavad üliõpilased vastutust väljenduda erialaselt võimalikult korrektselt. Selline vastutus võib kohati tekitada ka hirmu ülesande ees, luues ühtlasi soodsa pinna eelarvamuste tekkeks.

Et juba seal võivad tekkida mingid sellised nii-öelda lahkhelid, et tegelikult mingid sellised mitteametlikud terminid eesti keeles on juba olemas, mida füüsikud võib-olla omavahel kasutavad, aga kui sa ei tea neid, siis tõlgid omamoodi. Ja teine asi on just see allikast arusaamine, et võib väga rappa minna. (Üliõpilane_A)

Ja samas peale nagu selle ülesande täitmist /---/ nüüd ma olen ise kõik läbi teinud ja näinud, kuidas see protsess on, ja äkki ma nüüd ikkagi julgen ka mõne artikli veel kirjutada. Nüüd ta nagu praktiliselt läbi tehtuna ei tundugi nii hirmus või keeruline. (Üliõpilane_C)

Kui eespool mainitud puudused olid otseselt seotud vikiülesandega, siis kõik intervjueeritavad tõid esile ka selliseid puudusi, mis on oma olemuselt universaalsed. Nii näiteks nimetati suurt ajakulu, vähest õpimotivatsiooni ja allikmaterjali raskesti kättesaadavust. Suur ajakulu on otseselt seotud ka ebaselge töökorraldusega, mis võib õppeassistentide sõnul tuleneda sellest, et õppejõud kasutab vikiülesannet esimest korda või ta pole ise ühtki vikiartiklit kirjutanud ja ei oska seetõttu üliõpilaste spetsiifilistele küsimustele vastata.

Siis tegelikult on Vikipeedia artikkel ikkagi üsna ajamahukas ette võtta. Esiteks on allikate otsimine, siis sobiva info välja filtreerimine, kirjutamine, siis loogilisse järjestusse seadmine. Et kõik siis lõpuks nagu valmis saaks, tegelikult see võtab aega, et lõpuks näeks nagu puhas ja stiilne välja ka. (Üliõpilane_D)

... mis aitaks kaasa nende õppejõudude puhul, kes ei ole varem seda ülesannet oma ainetes teinud või kes nagu pole Vikipeediaga kokku puutunud, võib olla ise üks artikkel kirjutada ja siis saada kogenud õppeassistendilt tagasiside. Et võib-olla siis nad saavad ise ka aru, et mis siis nagu seal need põhiasjad on. (Õppeassistent_E)

Seega ilmneb nii õppejõudude enesekriitilistest märkustest kui ka õppeassistentide ja üliõpilaste kommentaaridest vajadus mõelda ülesande töökorraldus üksikasjalikult läbi ning leida viise, kuidas toetada üliõpilasi võõrkeelsete allikate, aga ka terminite eestindamisel. 


\section{Kokkuvõttev arutelu}

Kuna Wikipedia on konkurentsitult populaarseim (veebi)entsüklopeedia maailmas, ühtlasi kuulub ta enim külastatavate veebilehtede esikümnesse, on igati ootuspärane, et ka õpilased ja üliópilased kasutavad selles sisalduvat teavet, seda ka õppetöö eesmärgil. See on aga kutsunud nii õpetajates kui ka õppejõududes esile vastakaid arvamusi: ühed pooldavad Wikipedia keelustamist õppetöös, apelleerides selle sisulisele ebatäpsusele, ka subjektiivsusele, teised leiavad, et keelustamine tooks kasu asemel kahju, sest Wikipedia on paratamatus, millega tuleb leppida, kuid õppijatele on vaja õpetada, kuidas Wikipediaga vastutustundlikult ümber käia (vt nt Konieczny, 2012; Reilly, 2011). Selline seisukoht on kooskõlas Wikipedia juhendmaterjalis ${ }^{3}$ esitatud soovitusega vaadelda Wikipediat kui raamatukogu: see, et raamatukogus on mingi raamat (resp. artikkel) olemas, ei märgi veel kvaliteeti, kuid see ei tähenda, et raamatukogus ei oleks kvaliteetseid raamatuid (resp. artikleid) - neid tuleb osata üles leida. Levinud on arvamus, et õppetöös kasutatava vikiülesande kaudu saab muuta õppijate tarbimispõhiseid arusaamu Wikipediast ja juhtida seeläbi tähelepanu loomise ehk kirjutamise kui protsessi tähtsusele (Dawe \& Robinson, 2017). Veelgi enam, pooldajate leeri kuulub neidki, kes jagavad arusaama, et Wikipedia võimalused ei piirdu üksnes vastutustunde tekitamisega, vaid see kujutab endast ka mitmekülgset õpikeskkonda: Wikipedia pakub ainulaadset võimalust kaasata õppijaid protsessi, mille keskmes on kirjutamine reaalsele lugejaskonnale, žanritavade järgimine ning usaldusväärsuse, selguse ja eesmärgikohasuse tagamine (Crovitz \& Smoot, 2009).

Kuigi eestikeelne Vikipeedia jääb oma artiklite arvult ingliskeelsest Wikipediast kaugele maha, sest eesti keele kõnelejaskond on inglise keele omaga võrreldes tunduvalt väiksem ja kaastöö tegijate hulk seetõttu piiratum, on see oma sisult ingliskeelse sõsarversiooniga võrdväärne. Seega kehtivad Andrew Dalby (2007) sõnad „Wikipedia sisaldab mõttetusi kõrvu mõttekustega, ta sisaldab propagandat ja vigu kõrvu faktidega. Ta on äärmiselt ajakohane, välja arvatud siis, kui ta seda ei ole ..." (lk 7-8) ka Vikipeedia kohta. Nii leidub Vikipeediaski artikleid, mis pakuvad põhjalikku entsüklopeedilist teavet eri teemade kohta, kuid nende kõrval on ka selliseid, mida tuleks täiendada ja parandada, samuti on paljud valdkonnad artiklitega veel katmata (Zupping \& Noorma, 2018, lk 281). Kuna olenemata keeleversioonist on funktsioonide valik sama, pakub ka Vikipeedia õpetajatele ja õppejõududele mitmekesiseid võimalusi kasutada õppetöös eri tüüpi ülesandeid. Siinses artiklis oleme vaatluse alla võtnud Tartu Ülikooli väljendusõpetuse kursustel kasutatava vikiülesande.

Vt https://en.wikipedia.org/wiki/Wikipedia:Researching_with_Wikipedia. 


\section{Tervikartikli loomine etappide kaupa}

Vastusena uurimisküsimusele „Millistest töökorralduslikest etappidest koosneb Tartu Ülikooli väljendusõpetuse kursustel kasutatav vikiülesanne?" ilmneb fookusrühma intervjuudest, et kõigis ainetes lastakse üliõpilastel kirjutada uus (enamasti erialane) artikkel või täiendada mõnd olemasolevat artiklit. Selline tulemus on ootuspärane, sest kõik õppejõud, kes on otsustanud vikiülesande kasuks, kuuluvad väljendusõpetuse õppejõudude kogemuskogukonda, kus on ülesande põhialustes kokku lepitud. Küll aga on õppejõududel vaba voli otsustada, kuidas ülesannet praktikas rakendada. See seletab ka tõika, et õppejõud kasutavad vikiülesannet mõnevõrra erinevalt, kohandades seda nii enda kui ka üliõpilaste vajaduste järgi.

Vikiülesande korraldamisel lähtutakse protsessikeskse tekstiloome põhimõtetest ehk kirjutamine on jaotatud etappideks (Vikipeedia olemuse tutvustus, teemavalik ja infootsing, esimene mustand, tagasiside, puhtand, tagasiside ja artikli avaldamine). Olgugi et ülesande käigus pakutakse üliõpilastele ka teavet Vikipeedia olemuse ja vikiartikli kui tekstiliigi kohta, on põhifookus siiski kirjutamisel kui protsessil. See tähendab, et sellise ülesande kaudu arendatakse eeskätt mitmesuguseid õpioskusi, seevastu sotsialiseerimine ja akadeemiline kirjaoskus (oma kitsamas tähenduses) on jäänud tagaplaanile (vt Lea \& Street, 1998). Selline rõhuasetus tuleneb otseselt kursuse ainekavas sisalduvatest eesmärkidest, mis on seotud just digi- ja infopädevuse, uurimis- ja analüüsioskuse, kirjutamisoskuse ning kriitilise mõtlemise arendamisega ning mida on võimalik oskuslikult korraldatud vikiülesande kaudu saavutada. Seega ei ole vikiülesande eesmärk õpetada üliõpilasi Vikipeediasse kirjutama, vaid õpetada Vikipeedia artikli kaudu akadeemiliste tekstide kirjutamist.

Protsessikeskse tekstiloome üks olulisimaid etappe on tagasisidestamine (Jürine et al., 2017). Ka vikiartikli ülesandes on tagasisidel keskne koht: üliõpilased saavad oma artiklitele eri etappides kaasüliõpilastelt, õppeassistendilt ja/ või õppejõult vähemalt korra tagasisidet. Tagasiside vastuvõtmise kaudu areneb üliõpilaste koostööoskus, kuid sellisel viisil, kuidas praegu on ülesanne korraldatud, piirdub koostöö akadeemilise ringkonnaga. Ometigi rõhutatakse teaduskirjanduses, et Wikipedia kui õpikeskkonna eripära seisneb just võimaluses teha koostööd vikikogukonnaga ja saada artikli kohta kiiret reaalelulist tagasisidet (vt nt Konieczny, 2012; Reilly, 2011). Sellist tagasisidet väärtustavad üliõpilased sageli palju rohkem kui õppejõu oma (Reilly, 2011), sest õppejõud, isegi kui ta on Vikipeediasse artikleid kirjutanud, ei pruugi olla teadlik Vikipeedia toimimise üksikasjadest. Seetõttu võiksid väljendusõpetuse kursuse õppejõud, kes kasutavad vikiülesannet õppetöös, kaaluda võimalusi, kuidas kaasata Vikipeedia kogukonda kirjutamisprotsessi senisest enam. 


\section{Akadeemiline kirjaoskus, erialateadmised ja motivatsioon}

Fookusrühma intervjuud pakkusid uurimisküsimusele „Mis on vikiülesande tugevad küljed?" mitmesuguseid vastuseid. Nii õppejõud, õppeassistendid kui ka üliõpilased olid ühel meelel, et vikiülesande tugevaid külgi on võimalus arendada akadeemilise kirjaoskuse alla kuuluvaid õpioskusi: digi- ja infopädevust, uurimis- ja analüüsioskust ning kirjutamisoskust. Eraldi väärtusena tõsteti esile tagasiside andmise ja saamise oskust, mis on seotud koostööoskusega. Eelkirjeldatud uurimistulemused on ootuspärased ja kooskõlas teaduskirjanduses esitatud tähelepanekuga selle kohta, et ülesande käigus paraneb õppijate oskus kirjutada akadeemilisi tekste (Miller, 2014; Reilly, 2011). Küll aga ilmnes fookusrühma intervjuudest huvitava tendentsina, et ei üliõpilased ega õppejõud ei seostanud omandatud infootsinguoskusi ja allikakriitilisust (infopädevust) võimalusega rakendada neid oskusi olukordades, kus üliõpilased peaksid edaspidi lugejatena, Reilly (2011) mõistes tarbijatena, Vikipeediaga kokku puutuma. Üksnes óppeassistendid avaldasid lootust, et kui üliõpilased kirjutavad ise Vikipeediasse, oskavad nad ka teiste kirjutatud artiklitesse kriitiliselt suhtuda ega võta kogu infot tõe pähe.

Kuna väljendusõpetuse kursusel kirjutatakse enamasti erialaseid artikleid, siis tuli intervjuudest eraldi kategooriana esile erialateadmiste tähtsus. Võimalus valida endale meelepärane teema ja kirjutada sellest avalikkusele on omakorda seotud motivatsiooniga, mis moodustab vaatlusaluses materjalis samuti eraldi kategooria. Kui tavaliselt lastakse üliõpilastel kirjutada tekste, mis on mõeldud lugemiseks vaid õppejõule - Konieczny (2012) nimetab neid tabavalt kirjuta-hinda-hävita-ja-unusta-ülesanneteks -, siis vikiartikli sihtrühma moodustab avalikkus, kes võib kirjutatud artiklist ka reaalset kasu saada. Kuna sellisesse n-ö päris elu ülesandesse suhtuvad üliõpilased entusiastlikumalt kui traditsioonilistesse kirjutamisülesannetesse, soovides, et loodud tekst oleks võimalikult hea, siis on nad valmis ka rohkem pingutama (Miller, 2014). Sama tendents ilmnes ka praegustest uurimistulemustest.

\section{Raskused ja nende ületamine}

Kuigi fookusrühma intervjuudes osalejad leidsid, et vikiülesanne on mitmeti kasulik, nimetasid nad ka mõningaid raskusi, mis ülesandega kaasnevad, ja pakkusid raskuste ületamiseks välja võimalikke lahendusi. Vastusena küsimustele „Mis on vikiülesande nõrgad küljed?“ selgus intervjuudest, et tekstitasandil valmistab üliõpilastele raskusi võõrkeelsete allikate refereerimine ja terminite tõlkimine. Õppejõudude sõnul leidub ka neid üliõpilasi, kes otsustavad algupärase artikli kirjutamise asemel ingliskeelse vikiartikli tõlkimise kasuks. Hoolimata sellest, et vikiülesanne sobib ka võõrkeeleõppeks (ülesande 
kirjeldust vt Tardy, 2010) ja tõlketeema sisaldub väljendusõpetuse kursuse ainekavas, ei ole õppejõud seadnud eesmärgiks arendada vikiülesande kaudu üliõpilaste võõrkeele- või tõlkimisoskust. Praegusi uurimistulemusi arvestades vajab aga tõlketeema eritähelepanu, sest isegi kui õppejõud keelavad ära olemasolevate vikiartiklite tõlkimise eesti keelde, tuleb siiski leida viise, kuidas toetada üliõpilasi võõrkeelsete allikate refereerimisel. Niisamuti tuleb vikiülesande käigus käsitleda terminiküsimusi, sest artiklis on mõiste ja seda tähistav termin aukohal ning erialakeele arendamiseks on tähtis, et artiklis kasutataks sisuliselt ja keeleliselt korrektseid termineid. Koostöö mõne erialaaine õppejõuga või võimaluse korral lõputöö juhendajaga võiks olla lahendus, nagu ilmnes ka intervjuudest.

Raskused tõlkimisel ja terminite kasutamisel on seotud üliõpilaste üldise murega artiklite kvaliteedi pärast. Kuigi teaduskirjanduses rõhutatakse, et Vikipeedia võimaldab pakkuda õppijatele autentseid ülesandeid, mis suurendavad nende kaasatust ja seeläbi motivatsiooni (vt nt Dawe \& Robinson, 2017), tuleb arvestada ka sellega, et avalikkusele kirjutamine võib osale üliõpilastest olla tugev stressiallikas. Üliõpilased pelgavad, et neil jääb hea artikli kirjutamiseks erialastest teadmistest puudu, mistõttu võivad artiklitesse sattuda sisuvead. Kuna väljendusõpetuse kursustel kirjutatud artiklid on registreeritud enamasti ka eraldi Vikipeedia lehel, kardetakse, et sel viisil õppetööga seostatuna võivad ebakvaliteetsed artiklid heita halba valgust tervele ülikoolile. Seda muret ei jaganud küll kõik fookusrühma kuulunud üliõpilased, kuid ka selle probleemi lahendus võiks peituda tihedamas koostöös erialaõppejõudude ja juhendajatega.

Kui eeltoodud murekohad olid esitatud eeskätt üliõpilaste vaatenurgast, siis universaalsete probleemidena, ja mitte ainult vaatlusaluse aine kontekstis, mainisid kõik intervjueeritavad ajapuudust, töökorraldust, õpimotivatsiooni $j m$. Siinse uurimuse eesmärki silmas pidades väärib esiletõstmist töökorraldus. Kuigi ka üliõpilastele on tähtis, et õppejõul oleks vikiülesande korraldus hoolikalt läbi mõeldud, ilmneb uurimistulemustest, et see on veelgi tähtsam õppeassistentide jaoks. Kuna õppeassistendid toimivad sageli ühenduslülina õppejõu ja üliõpilaste vahel, peavad nad olema töökorraldusega hästi kursis. Ühtlasi võimaldab see neil lahendada ülesande käigus tekkivaid probleeme, sh kompenseerida mõnel juhul õppejõu väheseid teadmisi Vikipeedia toimimise kohta. Seevastu õppejõud, seades pilgu tulevikku, rõhutasid vajadust leida viise suunata üliõpilasi reflekteerima selle üle, kuidas vikiülesanne aitab kinnistada keeleteadmisi ja kujundada ülekantavaid oskusi. 


\section{Piirangud}

Kuna praegune uurimus esindab oma õpetamise arendamise valdkonda, oleme artikli autoritena vaatlusaluse teemaga paratamatult süvitsi seotud. Selline seos toob kaasa kahesuguseid piiranguid. Esiteks, kuna meil on tihe kokkupuude nii intervjueeritud õppejõudude kui ka õppeassistentidega ning kuna ka õppejõud ja õppeassistendid tunnevad üksteist, võis juhtuda, et nad ei soovinud avalikult rääkida raskustest, mis on ülesande korraldamisega kaasnenud, kartes kas ennast või kedagi teist halba valgusse seada. Niisamuti ei pruukinud osa üliõpilasi rääkida ülesandega seotud raskustest, sest artikli esimene autor oli vestluse juhataja ja nende õppejõud ning nad võisid end seetõttu ebamugavalt tunda. Teiseks, kuna uurime ülesannet, mida kasutame ise õppetöös, ei pruugi me süstemaatilisest analüüsist hoolimata olla tulemuste esitamisel ja tõlgendamisel nii objektiivsed, kui teadustöö seda nõuaks, mistõttu oleks hea kaasata edaspidi uurimisprotsessi mõni kõrvaline uurija, kes ei ole vaatlusaluse teemaga ise seotud.

\section{Tänusõnad}

Artikkel on valminud Tartu Ülikooli hea õpetamise grandi toel. Täname fookusrühma intervjuudes osalenud õppejõude, õppeassistente ja üliõpilasi sisukate arutelude eest.

\section{Kasutatud kirjandus}

Crovitz, D., \& Smoot, W. S. (2009). Wikipedia: Friend, not foe. The English Journal, 98(3), 91-97.

Dalby, A. (2007). Wikipedia(s) on the language map of the world. English Today, 23(2), 3-8. https://doi.org/10.1017/S0266078407002027

Dawe, L., \& Robinson, A. (2017). Wikipedia editing and information literacy: A case study. Information and Learning Sciences, 118(1/2), 5-16. https://doi.org/10.1108/ILS-09-2016-0067

Drisko, J. W., \& Maschi, T. (2016). Content analysis. New York: Oxford University Press.

Emigh, W., \& Herring, S. C. (2005). Collaborative authoring on the web: A genre analysis of online encyclopedias. System Sciences, 2005. HICSS'05. Proceedings of the 38th Annual Hawaii International Conference on System Sciences (pp. 99a-99a). https://doi.org/10.1109/HICSS.2005.149

Etikan, I., Musa, S. A., \& Alkassim, R. S. (2016). Comparison of convenience sampling and purposive sampling. American Journal of Theoretical and Applied Statistics, 5(1), 1-4. https://doi.org/10.11648/j.ajtas.20160501.11 
Fessakis, G., \& Zoumpatianou, M. (2013). Wikipedia uses in learning design: A literature review. Themes in Science and Technology Education, 5(1-2), 97-106.

Forte, A., \& Bruckman, A. (2006). From Wikipedia to the classroom: Exploring online publication and learning. International Conference of the Learning Sciences (pp. 182-188).

Hennink, M. M., \& Leavy, P. (2013). Focus group discussions. Cary: Oxford University Press.

Jürine, A., Leijen, D. A. J., \& Tragel, I. (2017). Tagasiside õppeprotsessis. Oma Keel, 1, $17-24$.

Jürine, A., \& Tragel, I. (2018). Mustandi kirjutamise kunst. Oma Keel, 1, 50-55.

Klaas-Lang, B. (2012). Eesti keel kõrgkoolis. Keel ja Kirjandus, 3, 229-231.

Knight, C., \& Pryke, S. (2012). Wikipedia and the university, a case study. Teaching in Higher Education, 17(6), 649-659. https://doi.org/10.1080/13562517.2012.666734

Konieczny, P. (2012). Wikis and Wikipedia as a teaching tool: Five years later. First Monday, 17(9). https://doi.org/10.5210/fm.v0i0.3583

Kuteeva, M. (2011). Wikis and academic writing: Changing the writer-reader relationship. English for Specific Purposes, 30(1), 44-57. https://doi.org/10.1016/j.esp.2010.04.007

Lea, M., \& Street, B. (1998). Student writing in higher education: An academic literacies approach. Studies in Higher Education, 23(2), 157-172. https://doi.org/10.1080/03075079812331380364

Mayring, P. (2000). Qualitative content analysis. Forum: Qualitative Social Research, 1(2). Retrieved from

http://www.qualitative-research.net/index.php/fqs/article/view/1089/2386.

Miller, J. (2014). Building academic literacy and research skills by contributing to Wikipedia: A case study at an Australian university. Journal of Academic Language \& Learning, 8(2), A72-A86.

Miller, N. (2005). Wikipedia and the disappearing „author“. ETC: A Review of General Semantics, 62(1), 37-40.

Morgan, D. L. (1993). Qualitative content analysis: A guide to paths not taken. Qualitative Health Research, 3(1), 112-121. https://doi.org/10.1177/104973239300300107

Oliver, J. T. (2015). One-shot Wikipedia: An edit-sprint toward information literacy. Reference Services Review, 43(1), 81-97. https://doi.org/10.1108/RSR-10-2014-0043

Patton, M. Q. (2002). Qualitative research \& evaluation methods (3rd ed.). Thousand Oaks, London, New Delhi: SAGE.

Pollard, E. A. (2008). Raising the stakes: Writing about witchcraft on Wikipedia. The History Teacher, 42(1), 9-24.

Reilly, C. A. (2011). Teaching Wikipedia as a mirrored technology. First Monday, 16(1). https://doi.org/10.5210/fm.v16i1.2824

Richards, K., \& Pilcher, N. (2018). Academic literacies: The word is not enough. Teaching in Higher Education, 23(2), 162-177. https://doi.org/10.1080/13562517.2017.1360270

Zupping, S., \& Noorma, M. (2018). Vikipeedia - mis, miks ja kellele? R. Raag \& J. Valge (toim.), Sõida tasa üle silla (lk 278-283). Tallinn, Tartu: EKSA. 
Tardy, C. M. (2010). Writing for the world: Wikipedia as an introduction to academic writing. English Teaching Forum, 1, 12-27.

Wingate, U. (2018). Academic literacy across the curriculum: Towards a collaborative instructional approach. Language Teaching, 51(3), 349-364.

https://doi.org/10.1017/S0261444816000264

Õppekava statuut (2018). Tartu Ülikool. Külastatud aadressil

https://humanitaarteadused.ut.ee/sites/default/files/www_ut/kehtib_alates_ 03_09_2018_oppekava_statuut.pdf

Õunapuu, L. (2014). Kvalitatiivne ja kvantitatiivne uurimisviis sotsiaalteadustes. Tartu: Tartu Ülikool. 


\title{
Developing students' academic literacies via Wikipedia-based tasks
}

\author{
Riina Reinsalua ${ }^{\text {al }}$, Sirli Zupping ${ }^{\mathrm{a}}$, Ene Voolaid ${ }^{\mathrm{b}}$ \\ ${ }^{a}$ Institute of Estonian and General Linguistics, University of Tartu \\ ${ }^{b}$ The Centre for Professional Development, University of Tartu
}

\section{Summary}

Since Wikipedia is by far the most popular (online) encyclopaedia in the world - ranking among the top ten most visited websites - it is only natural that students, too, actively make use of its vast amount of information. This, however, has caused a fair amount of polarising opinions among academics: while some of them tend to favour banning the use of Wikipedia in academic coursework altogether by pointing out its factual incorrectness and subjectivity, the others find that the ban could, in fact, do more harm than good. Academics belonging to the latter group find that Wikipedia inevitability should be accepted and students must be made more aware of how to use Wikipedia responsively (see Koniezny, 2012; Reilly, 2011). It is well established that using so called wiki tasks in teaching helps changing consumer-based notions and behaviour about Wikipedia and thereby highlights the importance of creativity or writing as a process (Dawe \& Robinson, 2017). Furthermore, amongst the pro-Wikipedia camp, there are those who suggest that using Wikipedia not only increases responsibility but can also be seen as a diverse learning environment. Wikipedia offers a unique opportunity to involve students in the process, which focuses on writing intended for real readership, follows genre traditions and raises credibility, clarity and sense of purpose. Importantly, this contributes to public debates about truth, accuracy and neutrality (Crovitz \& Smoot, 2009).

While Wikipedia gives opportunities for presenting genuine tasks to students, which thereby increase their involvement and motivation (e.g. Dawe \& Robinson, 2017), the wiki tasks are also seen as a way of developing the students' academic literacies. Academic literacies are often likened to academic writing skill but literacies are not by any means limited to only being able to write: academic literacies demonstrate one's competence to communicate adequately in academic settings, which in turn presupposes the ability to read, critically evaluate and present the information and create new knowledge:

Institute of Estonian and General Linguistics, Jakobi 2, 50090 Tartu, Estonia; riina.reinsalu@ut.ee 
both orally and in writing (Wingate, 2018). Since, based on this definition, academic literacies are no longer a single skill but rather a set of skills, Mary Lea and Brian Street suggest approaching academic literacies in the context of teaching writing as a three-fold phenomenon consisting of study skills, academic socialisation and academic literacies. It should be noted that academic literacies in a wider sense includes both study skills and academic socialisation, which enables to dissert writing in a more general institutional context. (Lea \& Street, 1998)

The integral task of writing or editing an article has been used in the University of Tartu since 2012; predominantly for "Estonian Orthography and Creative Composition" but due to the reform in self-expression studies, and in various iterations, also for "Estonian for Academic Purposes", "Communication in Estonian for Computer Science" and "Estonian Orthography and Composition." In these courses, which last one semester and credit students 3 ECTS, students have written more than 1700 Estonian language articles to the Estonian Wikipedia called Vikipeedia (mostly on topics from their specialised fields) under the supervision of eight university teachers. Due to the fact that wiki task is one of the most often used writing tasks of the self-expression course, the main goal of this article is to establish the ways in which wiki tasks would support the development of students' academic literacies. The article focuses on the following research questions:

1. How is a wiki task organised?

2. What are the strong points of a wiki task?

3. What are the weak points of a wiki task?

4. Which recommendations and guidelines could be given for organising wiki tasks better in the future?

In order to find answers to these questions, three focus group interviews were conducted in December 2018 and January 2019. The study selection consists of those university teachers of the self-expression course $(n=5)$ who have used wiki tasks in their courses, their teaching assistants $(n=6)$ and students $(n=7)$. Based on the principles of qualitative content analysis, the collected data was analysed inductively.

In terms of organising wiki tasks, the focus group interviews revealed that most often the task in self-expression courses is to write a new article in Estonian. In cases where there already exists an article on the chosen topic, students would have to edit and complement it. Despite the fact that wiki tasks are often organised somewhat differently in various courses, certain universal characteristics can be drawn. In the first stage, the particular focus is given to choosing the topic. The organising principles of the task are modelled after processcentred approach to text creation; the students receive individual feedback to 
their texts from teachers, assistants and/or fellow students and based on this they can amend their work before the final grading. Unequivocally, the most important part of the task is considered to be the feedback, which can be given either as aggregate feedback (a table with standard mistakes and solutions), individual feedback in a text file or presented on a Vikipeedia sub page or as video feedback (with screen monitoring function enabled).

The focus group interviews also revealed that the strong points of the task of writing Vikipeedia articles can be, by and large, divided into three groups: academic literacies, knowledge in a specialised field and motivation. Teachers, assistants and students agreed that wiki tasks can indeed help to develop several learning skills involved in academic literacies: digital competence (writing in text documents or Vikipeedia), information competence (searching info, evaluating sources), research and analysis skills (reading scientific texts) and reading skills (citing and referencing, organising text, spelling). As an added benefit, receiving and giving feedback competence was highlighted, which directly draws upon cooperation skills. Since Vikipeedia articles are usually written on specialist topics, which require reading specialist texts, wiki tasks greatly contribute to increasing one's professional knowledge. The participants of the focus group interviews pointed out that writing for public readership on topics that the writers themselves are passionate about, increases their learning motivation and offers them more meaningful learning experience.

Although the focus group interviews suggest that wiki task is indeed a great tool for teaching how to write academic texts, the interviewees also mention certain accompanying downsides. Most often, these concern difficulties arising from translating and choosing the right terms but are also to do with prejudices about the complications involved in the task. As the students of the focus group noted, wiki tasks could cause stress to some students due to the responsibility of having to write for the public. However, some of the above-mentioned difficulties are not specific to wiki tasks but are of a more general nature: e.g. lack of time, low learning motivation and difficulties in obtaining the source material.

Reflecting upon the future of wiki tasks, the teachers emphasised that we need to find ways of directing students to think as to how wiki tasks would help to strengthen their knowledge of language and shape their transferrable skills.

Keywords: academic text, academic writing, teaching communication skills, higher education 